\title{
Word Teaching Strategies in Story Reading for Preschool Children
}

\author{
Ana Carolina Arruda Miranda \\ Claudia Daiane Batista Bettio ${ }^{1}$ \\ Andréia Schmidt \\ ${ }^{1}$ Universidade de São Paulo, Ribeirão Preto, São Paulo, Brasil
}

\begin{abstract}
Shared book reading (SBR) as a teaching practice produces significant effects on development of verbal repertoires in children, especially when associated with strategies of explicit vocabulary teaching. This study aimed to test the cumulative effects of using word teaching strategies, during SBR sessions, on word learning by preschool children. Three sessions of SBR of the same story and a session of complementary activity about the words of the story read were carried out in a class of 13 children aged 4 to 5 years. It was identified significant children's gains, between pre and post-test, in matching-to-sample tasks for nouns and in naming tasks, both for nouns and for verbs. The results confirm the effectiveness of using word teaching strategies during SBR and their feasibility in the natural classroom context.

Keywords: storytelling; preschool age children; behavior analysis
\end{abstract}

\section{Estratégias de Ensino de Palavras em Leitura de História para Crianças Pré-Escolares}

\section{Resumo}

A leitura compartilhada de histórias (LCH) como prática de ensino produz efeitos significativos sobre o desenvolvimento de repertórios verbais em crianças, principalmente quando associada a estratégias de ensino explícito de vocabulário. Esse estudo teve como objetivo testar os efeitos cumulativos do uso de estratégias de ensino de palavras, a partir de sessões de LCH, sobre a aprendizagem de palavras por crianças pré-escolares. Foram realizadas três sessões de LCH de um mesmo livro e uma sessão de atividade complementar sobre as palavras da história, em uma classe com 13 crianças, com idades de 4 a 5 anos. Foram identificados ganhos significativos entre o pré e pós-teste no desempenho em tarefas de emparelhamento ao modelo para substantivos e nas tarefas de nomeação para substantivos e para verbos. Os resultados confirmam a eficácia do uso de estratégias de ensino de palavras durante LCH e a sua viabilidade no contexto natural de sala de aula.

Palavras-chave: narração de estórias, crianças em idade pré-escolar, análise do comportamento.

\section{Estrategias de Enseñanza de Palabras en Lectura de Historia para Niños Preescolares}

\begin{abstract}
Resumen
La lectura compartida de historias $(\mathrm{LCH})$ como práctica de enseñanza produce efectos significativos en el desarrollo de repertorios verbales en niños, principalmente cuando se asocia a estrategias de enseñanza explícita de vocabulario. Este estudio tuvo como objetivo evaluar los efectos cumulativos del uso de estrategias de enseñanza de palabras, a partir de sesiones de LCH, en el aprendizaje de palabras en preescolares. Se realizaron tres sesiones de LCH con un único libro y una sesión de actividad complementaria sobre las palabras de la historia, en una clase con 13 niños con edades entre 4 y 5 años. Al comparar las medidas pre y post test, se identificaron mejoras significativas en el desempeño en las tareas de emparejamiento al modelo para sustantivos y en las tareas de nombramiento de sustantivos y verbos. Los resultados confirman la eficacia del uso de estrategias de enseñanza de palabras durante LCH y su viabilidad en el contexto natural en clase.

Palabras clave: narración de historias; niños en edad preescolar; análisis de la conducta.
\end{abstract}

Aspects of the experience that support the learning of vocabulary are not available in the same way for children from different socioeconomic realities, having a direct influence on their linguistic developments (Hoff, 2003). This is directly related to a series of critical variables of the verbal interactions between adults and children. Such aspects interfere quantitatively and qualitatively, over time, in the size of the vocabulary of these children and in several other measures of linguistic development, which can lead to language difficulties (Hart \& Risley, 1995; Vallotton, Mastergeorge, Foster, Decker, \& Ayoub, 2017). When these difficulties are not identified and resolved in early childhood education, they can result in both a restricted vocabulary and losses in the literacy of these children in elementary school (Quinn, Wagner, Petscher, \& Lopez, 2015; Hirsh-Pasek \& Golinkoff, 2019).

An important way to prevent these problems is to arrange contingencies, especially in planned environments such as the school, to provide preschool children, particularly those in situations of social disadvantage, with an environment that allows them to develop complex verbal repertoires. Shared book reading (SBR) is a very common activity in the classroom that, when 
used for pedagogical purposes, can promote contingencies that contribute to the development of verbal repertoires in preschool and school children, while consisting of a naturally pleasurable activity (de Souza \& Bernardino, 2011). However, for SBR to become a pedagogical activity it needs to be planned so that it can provide teaching conditions.

In general, SBR is a situation in which one or more children hear a story read aloud by an adult (Flores, Santos, Amadeu, \& Dias, 2013). Among the benefits of shared reading, word learning (Horst, 2013; Wilkinson \& Houston-Price, 2013), word comprehension and phonological awareness (Korat, Shamir, \& Heibal, 2013), textual comprehension (Flores, Pires \& de Souza, 2014; Rogoski, Flores, Gauche, Coêlho, \& de Souza, 2015) and the increase in the ability to start conversations (Colmar, 2014) can be highlighted.

The vocabulary learning resulting from this activity can happen incidentally or based on the explicit teaching of words. Incidental learning occurs from information provided by the context in which a particular word is included (Nagy, Anderson, \& Hernam, 1987), mainly through repeated exposures to the same story (Horst, Parsons, \& Bryan, 2011; Sénéchal, 1997). Explicit word teaching, in turn, can assist in vocabulary learning when the reader provides direct instructions about the meaning of words, within or out of the context of the story (Beck \& McKeown, 1985; Bowne, Yoshikawa, \& Snow, 2016).

Providing situations for the occurrence of incidental learning of new words without the aid of teaching strategies presents some limitations. According to McKeown and Beck (2004), the information that the context provides about certain words can be incomplete and misleading, allowing the concept of the word to be formed from precipitated inferences. In addition, learning through this context occurs with low frequency (Beck \& McKeown, 1985). Therefore, researches developed in the last decade has investigated the effect of using different strategies for the explicit teaching of words through SBR (e.g., Hassinger-Das et al., 2016; Namasivayam et al., 2015; Wasik \& Hindman, 2014). The effects of different interventions on language development are usually assessed considering two dimensions of vocabulary: receptive and expressive. According to Araújo, Marteleto and Schoen-Ferreira (2010), the first concerns the individual's ability to comprehend language, while the second refers to the ability to use oral language to communicate with other members of the verbal community.
The strategies most commonly used in these studies are: highlighting the target word, which consists of directing children's attention toward the words to be taught, mainly through changes in the voice intonation when emitting the word (Namasivayam et al., 2015); explaining the meaning of the target word, by providing information about the words, such as synonyms and simplified meaning, among others (Namasivayam et al., 2015; Hassinger-Das et al., 2016); initiating conversations about the target word, especially with questions, in order to encourage children to have contact with the words, in addition to providing contexts for their emission throughout the conversations (Wasik \& Hindman, 2014); and using complementary activities, which consist of activities carried out in addition to the story reading, involving the words of the story to be taught (Hassinger-Das et al., 2016; Namasivayam et al., 2015).

The methodologies used in studies that implement this type of teaching strategy in SBR activities have many variations. The strategies can be tested either in isolation (e.g., Wasik \& Hindman, 2014) or combined, using more than one strategy during reading activities (Hassinger-Das et al., 2016; Namasivayam et al., 2015) and with different numbers of participants, with the vast majority of studies carrying out reading activities with pairs (Han, Moore, Vukelich, Buell, 2010) or small groups of children (Hassinger-Das et al., 2016; Pollard-Durodola et al., 2011). Few studies (e.g., Beck \& McKeown, 2007) have carried out this type of intervention in natural environments, as the readings do not occur within the classroom, and/or are not done for the entire class.

The context in which the words are taught varies widely among the different studies, so that in many of them more than one book is read (Beck \& McKeown, 2007; Han et al., 2010; Namasivayam et al., 2015; Pollard-Durodola et al., 2011), either to teach different words, or to teach the same words in different contexts. Although it is commonly considered that repeated exposure to unknown words in different contexts can facilitate learning, studies indicate that exposing children repeatedly to new words present in the same story is more effective. Throughout these repeated exposures, the plot becomes more and more familiar and predictable to children, enabling them to better understand the conditions that determine the meaning of unfamiliar words (Horst et al., 2011).

Despite this great variability among the methodologies tested, the main environment in which this 
type of intervention can assist in the development of children's vocabulary is the classroom. For this, it is necessary for this practice to be effective in conditions closer to a natural classroom situation, with it being essential that such interventions are tested with entire classes and in the school environment. In view of this, the general aim of the present study was to test the cumulative effects of using word teaching strategies, from SBR sessions, on the word learning of preschool children in a natural environment. For this, the study had the following specific aims: (a) to verify the cumulative effect of repeated readings of the same story, on the learning of target words (verbs and nouns) by the students; (b) to test the effects of the intervention on the receptive vocabulary, through matching to sample tasks; and (c) to test the effects of the intervention on the expressive vocabulary, through naming tasks.

\section{Method}

\section{Participants}

Participants of this study were 13 children (five girls and eight boys), aged between 4 and 5 years $(M=56.6$ months; $S D=4.1$, who attended a public daycare center in the city of Ribeirão Preto - SP. All the children studied in the same class and had their participation authorized by their parents, who signed a consent form. The study was approved by the Ethics Committee for Research with Human Subjects (CAAE No. 61182316.0.0000.5407).

All the children had their general development screened using the Denver II Developmental Screening Test, adapted to Portuguese (Pedromônico, Bragatto, \& Strobilus, 1999). A total of 11 children presented development considered "normal" and two children presented "risk of developmental delay". The auditory and expressive vocabulary assessment of the participating children was also performed, using the TVAud-A33o and TVExp-100o tests, respectively (Capovilla, Negrão, \& Damázio, 2011). Seven children presented a low score and six average scores for receptive vocabulary and, with respect to expressive vocabulary, seven children presented very low scores, two low scores, and four average scores.

\section{Location}

The activities of the reading sessions were carried out in the school classroom where the children studied. The tests were conducted in the school library.

\section{Instruments}

The development of the participating children was assessed using the Denver II Developmental Screening Test (Pedromônico et al., 1999), which is a screening test, applied individually with children aged 0 to 6 years, which allows identification of possible indicators of risk for developmental delay. The assessment is made through a set of tasks that assess behaviors expected for the child's age, in the areas of language, cognition, motor (fine and gross) and self-care. For each age assessed, certain tasks are performed, corresponding to the test items, in which the performances are scored with "passed", if the child is able to perform the task, or "failed", if not. Depending on the child's age, the fact of having performed each item or not can be interpreted as "advanced", "normal", "caution" or "delay". In the end, if there is no delay and at the most, one caution, the development is considered "normal"; and if there are two or more delays, there is a "risk of delay"; when the child refuses to perform the activity in one or more items, this is considered untestable.

The instruments used for the assessment of the children's vocabulary were the Auditory Vocabulary Test USP short version (TVAud-A33o - Cronbach's Alpha $=0.827)$ and the Expressive Vocabulary Test in its original form (TVExp-100o - Cronbach's Alpha=0.986) (Capovilla et al., 2011). Both tests are applied individually with children aged 1 to 6 years. In the Auditory Vocabulary Test, tasks of matching dictated words with pictures referring to these words are carried out. In the Expressive Vocabulary Test, picture naming tasks are performed. Each test generates a score that depends on the child's number of correct responses in the task. In the TVAud-A33o the maximum score is 33 points and in the TVExp-100o 100 points. Depending on the score obtained and the age, the child may have his/her performance classified as very high, high, medium, low or very low.

\section{Materials and Equipment}

Story Book. The book "Os Voos de Thiago", by Philip Waechter, published in 2016 by Editora Companhia das Letrinhas was used. The book was previously selected by the researchers and then evaluated by two judges, teachers who worked with children of the same age as the participants, who judged whether the book was appropriate for the children's age in terms of content, vocabulary and level of understandability of the plot. 
Test Book. For the assessment of the learning of words by the children, a "Test Book" was constructed containing pictures used to present naming and matching to sample tasks. The first part of this book evaluated the naming of pictures by the child. It consisted of colored pictures referring to 10 target verbs and 10 target nouns (unfamiliar words by the children and taught in the book reading sessions) and 10 control verbs and 10 control nouns (familiar to the children and not taught directly in the book reading sessions), with one picture on each page of the book. The second part of the Test Book, related to the matching to sample task, contained the same pictures as the first part (10 target nouns, 10 target verbs, 10 control nouns and 10 control verbs), however, with four pictures presented on each page, one in each quadrant of the page.

Target words and pictures. The target and control words (verbs and nouns) were selected by the researcher from the words present in the story "Os Voos de Thiago". Then, the words were submitted to two other judges, early childhood education teachers, who rated the target words as uncommon and the control words as common in the vocabulary of children aged 4 to 5 years. Subsequently, all the words (target and control) were evaluated, in relation to the degree of familiarity, by two other children of the same age group (these children claimed to know the control words and not to know the target words).

The target nouns were: net, valley, lemonade, compass, aerodrome, flock, autumn, pirouette, airline ticket and upset (rede, vale, limonada, bússola, aeródromo, revoada, outono, pirueta, bilhete aéreo and arreliado) (adjective selected to complete the total of 10 target nouns). The control nouns were: tree, house, window, sea, toothbrush, child, birds, sun, flowers and backpack (árvore, casa, janela, mar, escova de dente, criança, pássaros, sol, flores and mochila). The pictures referring to the nouns represented objects, landscapes and/or people. The target verbs were: gossip, greet, dialog, transport, dismiss, aspire, accompany, reflect, hiss and leave (fuxicar, saudar, dialogar, transportar, despedir, aspirar, acompanhar, refletir, silvar and partir). The control verbs were: run, share, eat, kiss, sing, crawl, hug, fly, drink and sit (correr, dividir, comer, beijar, cantar, engatinhar, abracar, voar, beber and sentar). The pictures that illustrated the verbs consisted of scenes composed of people performing the actions.

Picture Cards. Twenty cards were made containing colored pictures that represented the target words (nouns - 10 cards, and verbs - 10 cards). The pictures were extracted from the internet and referred to the same words used in the Test Book. The pictures related to the nouns contained objects, landscapes and/or people, while the pictures of the verbs showed people performing the actions. Sticky tape was attached behind these cards, so that the cards could be attached to the Complementary Activity Panel.

Complementary Activity Panel. A panel was made with EVA foam in purple and green, with a wooden frame. Sticky tape was attached to the center of this panel so that the Picture Cards could be attached during the performance of the Complementary Activity (see section "Procedure"). The panel was divided in half so that, on one side, the cards referring to the verbs could be attached, and on the other, the cards referring to the nouns.

For filming the activities, a Sony Handycam camcorder, model HDR-CX220 and a tripod were used.

\section{Procedure}

The design of this study was quasi-experimental, with pre- and post-test and an intermediate probe. The explicit vocabulary teaching strategies were implemented individually in each reading session by one of the researchers in an increasing order of complexity. This order of complexity was configured according to the level of comprehension of the words that each strategy demanded from the children so that they could actively participate in the reading activity.

Initially, the strategy "Highlighting the target word" was used, only directing the child's attention toward unfamiliar words; in the following session, the strategy "Explaining the meaning of the target word" was used, providing the definition of the target words throughout the reading; in the third session, the strategy "Starting conversations about the target word" was used, requesting that children behave as speakers and listeners in situations involving the target words after reading the story; and finally, the "Complementary Activities" strategy was used, engaging children in a playful activity related to the words. Each step of the procedure is described in the sections below.

Pre-test: First, a pre-test was carried out with the Test Book to assess whether children related the pictures in the test book to the target words and control words, through naming tasks (naming probes) and matching to sample tasks (matching probes). The Test Book was presented to the children by one of the researchers, in the library of the daycare center. Each child performed the pre-test individually, starting with the naming task and then the matching task. In the first 
task, each child was asked to name the pictures that were being presented. Then, the matching task was started. Each child was asked to stick a sticker on the picture referring to the word dictated by the researcher. None of the responses issued by the child were differentially reinforced, so that after each response, the next trial was initiated. At the end of the pre-test, the researcher thanked the child and accompanied he/she to the classroom.

Reading sessions 1 and 2: The aim of these sessions was to implement the strategies "Highlighting the target word" and "Explaining the meaning of the target word" while reading the book for the group of participating children. In each session, one strategy was used and the same book was read. Three days after the application of the pre-test, the first reading session was carried out, using the strategy "Highlighting the target word", which consisted of emphasizing the target word by changing the voice intonation when saying the word during the reading and repeating it, then returning to the sentence in which the word appeared. For example: "Thiago saw a flock. He saw a flock!". This strategy was used throughout the entire reading of the book, each time a target word appeared in the story (verb or noun). Each word was highlighted only once, even if it appeared more often throughout the story. The second reading session was carried out four days after the first session. On that occasion, the strategy "Explaining the meaning of the target word" was used, which consisted of providing a definition of the target word from information probably known to the child. Throughout the reading, when the target words appeared in the story, the researcher interrupted the reading and gave the meaning of the word read. For example, "to Greet is when you say 'Hi' to someone". At the end of the definition, the sentence in which the word was found was repeated and the course of the story was resumed.

Three days after the second reading session, an intermediate probe was performed, with an application procedure exactly the same as the pre-test.

Reading sessions 3 and 4: In these sessions, the strategies "Starting conversations about the target word" and "Complementary Activity" were implemented based on the reading of the same story as the previous sessions. Four days after the intermediate probe, the third reading session was held, using the strategy "Starting conversations about the target word" with the help of the Picture Cards (see section "Materials and Equipment"). This strategy consisted of starting conversations about the unknown word with questions about the context of the story (contextualized) or about the child's daily life (decontextualized). During the session, the whole book was read without interruption and, after the reading was finished, with the children still in a circle, the researcher showed each card to all the children, asking what the picture on the card was, or what the people were doing in the picture, so that the children identified the word referring to that picture and emitted it. Then, the researcher asked questions about the picture on the card within the context of the story (contextualized) - for example: "When did the flock appear in the story?"; and within the context of the daily lives of the children (out of context), for example: "Has anyone ever seen a flock?". This procedure was repeated with all the cards.

Three days after the third session, the fourth and last session was carried out, using the strategy "Complementary Activities", without reading the book, with the help of the Picture Cards and the Complementary Activity Panel. The complementary activity used involved a matching to sample task in a playful context. In this activity, the 10 cards referring to verbs were placed on a table in front of half the class and the other 10 cards referring to nouns were placed on another table in front of the other half of the class.

This task was performed in a group so that children that had not yet related the target words to their respective pictures could be helped by their colleagues of the group. One of the researchers said a word and asked each child to identify, on the table, the card with the picture referring to the word and then paste it on the Panel. All the children participated in the activity, however, some participated twice due to the amount of cards used.

Four days after the fourth and final session, the post-test was performed, in exactly the same way as the pre-test and the intermediate probe. Two weeks after the application of the post-test, all the children were individually assessed for general development and language development by two of the researchers, also in the daycare center's library, in order to obtain information that characterized the sample of participating children. The researchers asked the child to sit in a chair, in front of a table. The child's developmental assessment was then started (Denver II Test) and then the language assessments were carried out (TVExp-100o and TVAud-A33o). The total time for the assessments with each child was 30 minutes. At the end, the child was taken back to the classroom or other place where the class was. 


\section{Data analysis}

Correct responses and errors of each child in the naming and matching to sample tasks were computed in the pre-test, intermediate probe and post-test. Then, the group's mean number of correct responses in each test was calculated. The results obtained went through a statistical analysis for the comparison of linked sample data, composed of the mean of correct responses in the naming and matching tasks (Friedman test). The R software (R Core Team, 2018) was used. Any results with $p \leq 0.05$ (95\% confidence level) were considered significant. When the comparison between the three probes (pre-test, intermediate and post-test) from the Friedman test showed $p \leq 0.05$, a post hoc with the paired Wilcoxon test was performed so that it was possible to identify which pairs of probes showed significant differences between them.

\section{Results}

Table 1 shows the individual results of the participants in the learning tests (matching and naming probes) for the target words, as well as the mean of the group, in each type of probe, by type of word (nouns and verbs). Although 13 children participated in the study, child P11 did not perform the final probe, therefore his data was removed from the analysis.
In general, it can be observed in Table 1 that all the children showed increases in the scores obtained in the naming and matching measures, when comparing the pre- and the post-test. In absolute terms, the mean number of correct responses of the children in the matching tasks was higher than in the naming tasks, in all probes. The increases identified between the preand post-test were measured in percentage with respect to the total number of probes. In the matching probes there was an increase of $15.8 \%$ of correct responses for the nouns and $13.3 \%$ for the verbs. In the naming tasks there was an increase of $27.5 \%$ in correct responses for the nouns and $10.8 \%$ for the verbs.

In the pre-test, the children's performance in the matching tasks was better than in the naming tasks: on average, the children correctly matched six nouns and approximately three verbs in the tests, while they named, on average, approximately one picture of a noun and no pictures representing a verb, which indicates an initial expressive performance lower than the receptive performance. Despite this, as presented in Table 1, the mean number of correct responses increased for all participants throughout the probes, even though the mean number of correct responses in the matching tasks remained higher than the mean number of correct responses in the naming tasks, and the mean number of correct responses for the nouns remained

Table 1.

Number of Correct Responses per Participant and Mean Scores of the Group in the Matching to Sample and Naming Probes, for the Nouns and Verbs in the Pre-test, Intermediate Probe and Post-test

\begin{tabular}{|c|c|c|c|c|c|c|c|c|c|c|c|c|c|c|c|}
\hline Participants & & & P1 & $\mathrm{P} 2$ & P3 & P4 & P5 & P6 & P7 & P8 & P9 & P10 & P12 & P13 & Mean \\
\hline \multirow[t]{6}{*}{ Matching } & Nouns & PT & 8 & 6 & 5 & 8 & 4 & 5 & 8 & 2 & 9 & 7 & 7 & 3 & 6.00 \\
\hline & & INT & 9 & 7 & 6 & 8 & 6 & 7 & 7 & 3 & 8 & 7 & 7 & 5 & 6.67 \\
\hline & & POT & 10 & 6 & 7 & 9 & 6 & 9 & 7 & 3 & 10 & 9 & 9 & 6 & 7.58 \\
\hline & Verbs & PT & 3 & 2 & 3 & 1 & 0 & 5 & 1 & 0 & 4 & 5 & 4 & 6 & 2.83 \\
\hline & & INT & 6 & 5 & 4 & 3 & 2 & 7 & 1 & 3 & 6 & 5 & 2 & 5 & 4.08 \\
\hline & & POT & 6 & 2 & 4 & 5 & 2 & 8 & 1 & 2 & 7 & 6 & 3 & 4 & 4.17 \\
\hline \multirow[t]{6}{*}{ Naming } & Nouns & PT & 2 & 1 & 1 & 1 & 1 & 1 & 1 & 0 & 2 & 0 & 0 & 0 & 0.83 \\
\hline & & INT & 0 & 2 & 2 & 2 & 1 & 1 & 0 & 0 & 3 & 2 & 2 & 1 & 1.33 \\
\hline & & POT & 9 & 3 & 3 & 2 & 1 & 5 & 4 & 1 & 5 & 4 & 5 & 1 & 3.58 \\
\hline & Verbs & PT & 0 & 0 & 0 & 0 & 0 & 0 & 0 & 0 & 0 & 0 & 0 & 0 & 0 \\
\hline & & INT & 0 & 0 & 0 & 0 & 1 & 0 & 0 & 1 & 0 & 0 & 0 & 0 & 0.17 \\
\hline & & POT & 2 & 1 & 1 & 0 & 0 & 2 & 0 & 0 & 2 & 3 & 1 & 1 & 1.08 \\
\hline
\end{tabular}

Note: PT: Pre-test; INT: Intermediate probe; POT: Post-test 
higher than the mean number of correct responses for the verbs.

Figure 1 shows the mean number of correct responses of the group in relation to verbs and nouns, in both the matching tasks and naming tasks.

As can be seen in Figure 1, there was a significant increase in the mean number of correct responses in the matching tasks for nouns between the pre-test and the post-test (from 6 to $7.58-p=0.002$ ), but not between the pre-test and the intermediate probe $(p=0.381)$ or between the post-test and the intermediate probe $(p=0.115)$. There was also no statistically significant difference in the group's performance between the different probes with regard to the matching tasks for the verbs $(p>0.06)$. In the naming tasks, there was a significant increase in the mean number of correct responses between the pre-test and the post-test $(p<0.01)$, and also between the intermediate probe and the posttest $(p=0.01)$ for the nouns. For the verbs, there was a significant increase only between the pre-test and the post-test $(p=0.005)$.

In general, in the matching tasks there was a significant improvement in the mean number of correct responses of the participants, between the pre-test and the post-test, for the nouns, but not for the verbs, despite the increase in the mean number of correct responses recorded in this measure. In the naming probes for the nouns, a significant increase in the mean number of correct responses was observed for each probe (except from the pre-test to the intermediate probe), however, for the verbs this significant increase was observed only between the pre-test and the post-test.

\section{Discussion}

The main aim of this study was to test the effects of using four explicit word teaching strategies ("Highlighting the target word", "Explaining the meaning of the target word", "Starting conversations about the target word" and "Complementary Activities"), used during sessions of shared reading of the same story, in relation to the word learning by children of preschool age, in a natural classroom environment.

The results showed that the use of the strategies of explicit word teaching, in a cumulative way, produced learning of the target words by the children. A progressive increase in the mean number of correct responses was observed, both in the matching probes (which are a measure of receptive vocabulary) and in the naming probes (a measure of expressive vocabulary), which indicates that word learning started in the first sessions of teaching, increasing until the end of the procedure. The implementation of three reading sessions, each using one strategy, and the performance of a fourth session using only the "Complementary Activities" strategy, were sufficient to provide this learning.

The gains in learning the target words of preschool children, identified in these results, are in
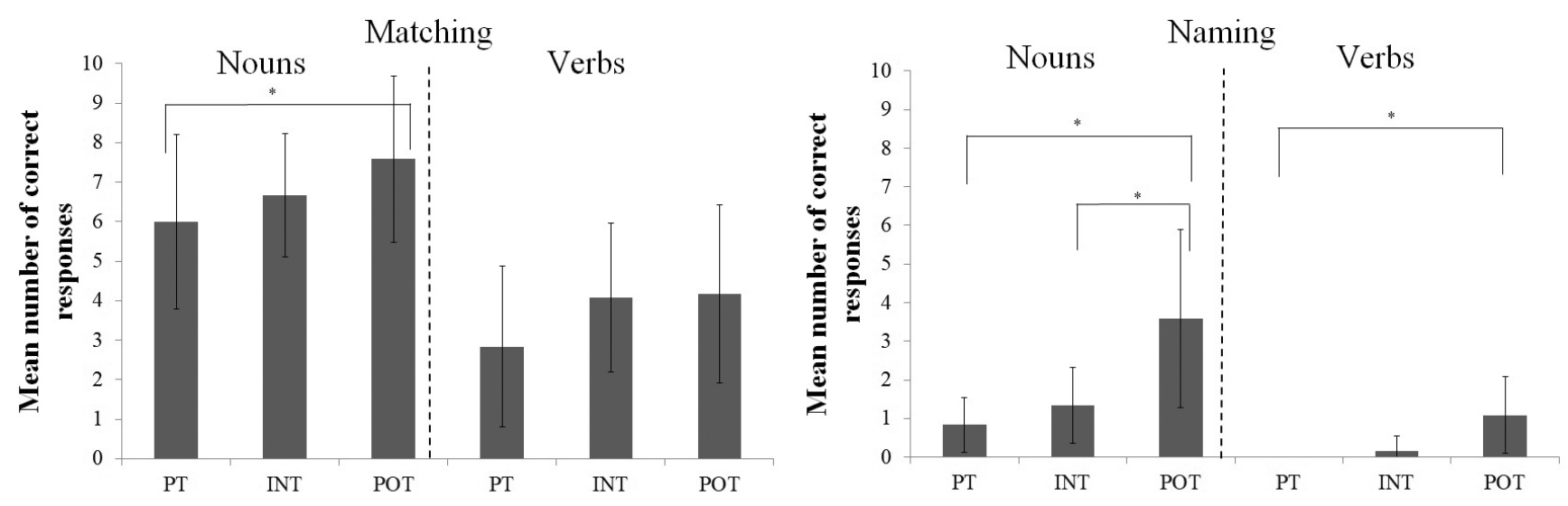

${ }^{*} p<0.05$

Figure 1. Mean number of correct responses of the participants in the matching and naming tasks, for the nouns and verbs, in the pre-test, intermediate probe and post-test evaluations. 
agreement with other studies that used strategies of explicit teaching of words from shared book reading. These studies suggest that the use of teaching strategies aimed at exposing children to information related to the words found in the stories and to different situations that enable their interaction with these words, in the expressive and receptive domains, are able to assist in the development of language by facilitating the occurrence of learning processes (Coyne, McCoach, \& Kapp, 2007; Beck \& McKeown, 2007; Han et al., 2010; Hassinger-Das et al., 2016; Namasivayam et al., 2015; Pollard-Durodola et al., 2011).

The intervention proposed in the present study was implemented aiming to allow the learning of words to occur incidentally, as well as from strategies of explicit teaching of words. To make incidental learning possible, it was essential to use the same book in all the reading sessions. The methodology used allowed the children to have access to four different opportunities for contact with the target words, configuring multiple exposures to the same words, in a distributed way, within the same plot. According to Horst et al. (2011), this may have enabled the story to become more and more known and, with this, the child could pay attention to different stimuli of the story.

The use of explicit vocabulary teaching strategies in SBR activities, on the other hand, represents a differentiated and more specific performance, with the arrangement of contingencies capable of supporting the occurrence of learning processes beyond those already provided by only repeated readings of the story. Intervention studies regarding SBR (e.g., Milburn, Girolametto, Weitzman, \& Greenberg, 2014; Namasivayam et al., 2015), in general, use different strategies together and do not test the separate effect of each one. Although the present work also evaluated the cumulative effect of the different strategies, considering that each one had different characteristics, it is possible to make comparisons between them and present conceivable explanations regarding their effects on the students' vocabulary.

The strategies used are capable of providing word learning by establishing relationships between stimuli, possibly resulting in the formation or extension of classes already existing in the children's verbal repertoire. In terms of stimulus control, learning the meaning of words requires the formation of classes that include the words themselves and their referents (verbal and/or visual) (de Rose, 1993; Sidman, 1994). The word "greet", for example, relates to a specific action (e.g., waving or saying "hi) and its graphic representations (e.g., photos or pictures representing that action; or written words). The meaning of this verb, therefore, lies in the relation established between it and the stimuli that compose the class in which it participates. According to de Rose (1993), the expansion of existing classes can occur when unknown stimuli are related to already known stimuli. The teaching strategies used in this study acted in this direction, however, each of them had specific characteristics and contingencies arranged in different ways, which probably had different effects on the formation and/or expansion of classes.

The first strategy used, "Highlighting the target word", aimed to direct the children's attention toward the target (unfamiliar) words through changes in the voice intonation when emitting the word. This strategy did not explicitly establish any relation between the target word and any other stimulus present in the story (word or picture, for example). Even so, the role of this strategy is explained by the fact that, in order for learning to occur, the highlighted word must first acquire the function of discriminative stimulus for the emission of responses by the children. These responses should focus on identifying information from the story that relates to the words, enabling the comprehension of their meanings. The formation of relations between stimuli, in this case, necessarily depends on information that the plot of the story itself provides about the word (context) and on the possibility for the child to establish these relations based on the narrative.

The process of forming relations between the target word and other stimuli becomes more likely with the use of the following strategy, "Explaining the meaning of the target word", since information about the word taught is provided, in addition to the information present in the story. During the narration, the adult presents simple definitions, composed of verbal stimuli that can be related to the target word. In this case, the aim is to explicitly relate the word taught to other words, which are more likely to be known by the children. The "unknown" words could, with this strategy, become part of pre-existing stimulus classes.

The last two strategies, "Starting conversations about the target word" and "Complementary Activities", provided different contexts for the child to have contact with the target word. There was not only the possibility that the students could establish and expand possible relations between a greater number of stimuli, such as words and pictures, but also that they had the 
opportunity to behave in different ways in relation to the target words (e.g., emitting the word in a natural context, such as when answering contextualized and decontextualized questions about the words).

Considering the results, it was possible to identify that the use of the set of strategies described was effective in providing conditions for the children to establish relations between the target words and other stimuli, configuring learning processes identified in other studies that also used a combination of different strategies (Beck \& McKeown, 2007; Han et al., 2010; Hassinger-Das et al., 2016; Namasivayam et al., 2015; Pollard-Durodola et al., 2011).

Analyzing the matching and naming tasks more specifically, it was found that the performance of the participants in the matching probes was superior to that of the naming tasks from the pre-test. However, although the intervention performed had an effect on both measures, more significant gains were identified in the naming tasks (expressive vocabulary), both for the verbs and the nouns. Therefore, despite the study by Hassinger-Das et al. (2016) having identified greater gains in activities that involve receptive vocabulary, this effect was not found in the present study.

As this more significant effect on naming tasks was identified only between the pre-test and the posttest, and between the intermediate probe and the post-test, apparently the last two sessions performed had a greater influence on the children's learning. This fact may be related to the use of the strategy "Starting conversations about the target word", since the objective of this was to provide discriminative stimuli so that the children could use the target words in their speech. Some studies indicate that strategies that promote children's active participation during reading activities, answering questions and engaging in conversations, are directly related to vocabulary gains due to helping them to discriminate the context of use of each word (Gonzalez et al., 2014; Walsh \& Blewitt, 2006; Wasik \& Hindman, 2014), mainly with gains in the expressive vocabulary (Sénéchal, 1997).

In addition, it is possible that the use of this strategy, as well as the "Complementary Activity" strategy, influenced the gains in naming of the children participating in the study, as they were carried out with the help of Picture Cards, in tasks very similar to the naming tasks used in the different probes, but with different pictures. This, however, is only a possible interpretation of the results presented and it is necessary to consider that the study design used does not allow the effect of the specific strategies to be separated from the cumulative effect of using all the strategies throughout the sessions, as also highlighted by Pollard-Durodola et al. (2011).

In general, it was found that shared book reading activities can be performed, with the teaching of words as one of the objectives. For this, it is necessary to plan the activity in advance. This preparation contributes with a prior selection of the words to be taught and, with this, it is possible to determine how they will be defined and how they will be presented in the context of the reading.

Beck and McKeown (1985) emphasized the importance of planning for the use of instructions aimed at teaching vocabulary, mainly considering aspects of comprehension and use of vocabulary to which the instructions used are directed; the type of word that best suits each type of instruction; and the population to which the teaching will be directed. However, according to studies by Costa, Mariano, Oliveira and Crenitte (2017), few teachers plan reading activities before starting them and most of them demonstrate little knowledge about effective ways to intervene regarding the children's vocabulary. These results indicate the importance of training programs for teachers, directed toward improving the shared reading activities carried out in the classroom.

Despite the positive effects achieved with the intervention performed, it is necessary to discuss some of its limitations. Initially, the small sample size created difficulties, mainly due to the great variability found in the children's individual performances, making it impossible to use parametric tests for the statistical analysis of the data. However, this variability reinforces the need to plan reading activities that allow the participation of all children, taking into account the specificities of each one, in order to provide similar learning conditions.

Another limitation refers to the children's entry performance in the matching tasks in relation to the nouns. This factor may be related to some characteristics of the study, such as the use of target words that were not completely unknown, which also highlights a difficulty in finding words unfamiliar to the majority of children in commercial books. In addition, it is possible that the way in which the pictures in the Test Book were organized made it possible for the children to deduce the correct response, responding by exclusion in the matching tasks, by searching the correct alternatives for an unknown picture that could be related to the unknown spoken word, as reported in some studies 
(e.g., Cabral, de Assis, \& Haydu, 2012; Grassmann, Schulze, \& Tomasello, 2015).

In addition, the low scores displayed by the children in relation to the verbs may be related to the pictures that were made available for the naming and matching tasks, which may have presented low discrimination, making it difficult for the children to identify the target word they referred to. For example, this was evident from situations such as when presented with the picture referring to the word "dismiss", many children answered "saying hi", because they were unable to discriminate the difference between the two actions in the pictures. This limitation may also be related to the difficulty found by the researcher in reproducing actions by means of pictures, since actions involve movement, which is difficult to represent in static pictures.

Despite these limitations, it was possible to clearly identify the occurrence of learning processes from the activities carried out in this study. The findings of the study conducted indicate the importance, of both the reading, planning and arranging opportunities in the children's routine so that they have contact with new words and can use them in different contexts. Accordingly, it is important that future studies in this area also explore, in larger classes, aspects related to the applicability of the strategies used. In addition, new studies should develop more accurate non-standard (naming and matching) measurement instruments. It is also important to highlight the importance of studies that develop teaching and monitoring strategies for teachers so that they can implement shared reading strategies with their students.

\section{References}

Araújo, M. V. M., Marteleto, M. R. F., \& Schoen-Ferreira, T. H. (2010). Avaliação do vocabulário receptivo de crianças pré-escolares. Estudos de Psicologia (Campinas), 27(2), 169-176. doi: 10.1590/ S0103-166X2010000200004

Beck, I., \& Mckoewn, M. G. (2007). Increasing young low-income children's oral vocabulary repertoires through rich and focused instruction. The Elementary School Journal, 107(3), 251-271. doi: $10.1086 / 511706$

Beck, I., \& Mckoewn, M. G. (1985). Teaching vocabulary: Making the instruction fit the goal. Educational Perspectives, 23(1), 11-15. Retirado de https://www.researchgate.net/profile/
Margaret_Mckeown/publication/234746230_ Teaching_Vocabulary_Making_the_Instruction_ Fit_the_Goal/links/55252b6c0cf2b123c51794ba. pdf

Bowne, J. B., Yoshikawa, H., \& Snow, E. C. (2016). Relationships of teachers' language and explicit vocabulary instruction to students' vocabulary growth in kindergarten. Reading Research Quarterly, 52(1), 7-29. doi: 10.1002/rrq.151

Cabral, R. P., Assis, G. J. A., \& Haydu, V. B. (2012). Emergência de leitura em crianças com fracasso escolar: Efeitos do controle por exclusão. Revista Brasileira de Terapia Comportamental Cognitiva, 14(3), 88-101. doi: 10.31505/rbtcc.v14i3.550

Capovilla, F. C., Negrão, V. D., \& Damázio, M. (2011). Teste de Vocabulário Auditivo e Teste de Vocabulário Receptivo: Validados e normatizados para o desenvolvimento da compreensão da fala dos 18 meses aos 6 anos de idade. São Paulo: Memnon

Colmar, S. H. (2014). A parent-based book-reading intervention for disadvantaged children with language difficulties. Child Language Teaching and Therapy, 30(1), 79-90. doi: 10.1177/0265659013507296

Costa, A. R. A., Mariano, T. C. B., de Oliveira, A. N., \& Crenitte, P. A. P. (2017). Conhecimento de professores sobre estimulação da linguagem via narração de histórias. Distúrbios da Comunicação, 29(2), 330341. doi: 10.23925/2176-2724.2017v29i2p330-341

Coyne, M. D., McCoach, D. B., \& Kapp, S. (2007). Vocabulary intervention for kindergarten students: Comparing extended instruction to embedded instruction and incidental exposure. Learning Disability Quarterly, 30(2), 74-88. doi: 10.2307/30035543

de Rose, J. C. (1993). Classes de estímulos: Implicações para uma análise comportamental da cognição. Psicologia: Teoria e Pesquisa, 9(2), 283303. Retirado de https://www.researchgate.net/ publication/275519966_Classes_de_estimulos_ Implicacoes_para_uma_analise_comportamental_da_cognicao

de Souza, L. O., \& Bernardino, A. D. (2011). A contação de histórias como estratégia pedagógica na educação infantil e ensino fundamental. Educere et Educare: Revista de Educaşão, 6(12), 235-249. Retirado de http://e-revista.unioeste.br/index.php/ educereeteducare/article/view/4643

Psico-USF, Bragança Paulista, v. 25, n. 4, p. 671-683, out./ dez. 2020 
Flores, E. P., Santos, G. F. de A., Amadeu, L. F. da M., \& Dias, A. R. (2013). Leitura compartilhada em um hospital pediátrico: Analise do comportamento verbal dos contadores. Psicologia: Reflexão \&Critica, 26(4), 711-719. doi: 10.1590/ S0102-79722013000400011

Flores, E. P., Pires, L. F., \& de Souza, C. B. A. (2014). Dialogic reading of a novel for children: Effects on text comprehension. Paidéia, 24(58), 243-251. doi: 10.1590/1982-43272458201412

Gonzalez, J. E., Pollard-Durodola, S., Simmons, D. C., Taylor, A. B., Daviz, M. J., Fogarty, M., \& Simmons, L. (2014). Enhancing preschool children's vocabulary: Effects of teacher talk before, during and after shared reading. Early Childhood Research Quarterly, 29, 214-226. doi: 10.1016/j. ecresq.2013.11.001

Grassmann, S., Schulze, C., \& Tomasello, M. (2015). Children's level of word knowledge predicts their exclusion of familiar objects as referents of novel words. Frontiers in Psychology, 6, 1-8. doi: 10.3389/ fpsyg. 2015.01200

Han, M., Moore, N., Vukelich, C., \& Buell, M. (2010). Does play make a difference? How play intervention affects the vocabulary learning of at-risk preschoolers. American Journal of Play, 3(1), 82-105. Retirado de https:/ / eric.ed.gov/?id=EJ1070222

Hart, B., \& Risley, T. (1995). Meaningful differences in the everyday experience of young American children. Baltimore: Paul H Brookes Publishing.

Hassinger-Das, B., Ridge, K., Parker, A., Golinkoff, R. M., Hirsh-Pasek, K., \& Dickinson, D. K. (2016). Building vocabulary knowledge in preschoolers through shared book reading and gameplay. Mind, Brain, and Education, 10(2), 71-80. doi: 10.1111/ mbe.12103

Hirsh-Pasek, K., \& Golinkoff, R. M. (2019). Put your data to use: Entering the real world of children and families. Perspectives on Psychological Science, 14(1), 3742. doi: $10.1177 / 1745691618815161$

Hoff, E. (2003). The specificity of environmental influence: Socioeconomic status affects early vocabulary development via maternal speech. Child Development, 74(5), 1368-1378. Retirado de: http:// citeseerx.ist.psu.edu/viewdoc/download?doi=10. 1.1.324.4930\&rep $=$ rep1\&type $=$ pdf
Horst, J. S. (2013). Context and repetition in word learning. Frontiers in Psychology, 4(149), 1-11. doi: 10.3389/fpsyg.2013.00149

Horst, J. S., Parsons, K. L., \& Bryan, N. M. (2011). Get the story straight: Contextual repetition promotes word learning from storybooks. Frontiers in Psychology, 2(17), 1-11. doi: 10.3389/fpsyg.2011.00017

Korat, O., Shamir, A., \&Heibal, S. (2013). Expanding the boundaries of shared book reading: E-books and printed books in parent-child reading as support for children's language. First Language, 33(5), 504-523. doi: 10.1177/0142723713503148

McKeown, M. G., \& Beck, I. L. (2004) Direct and Rich Vocabulary Instruction. In Baumann, J. F., \& Kame'enui, E. J. (Eds.), Vocabulary Instruction (pp. 13-27). New York: Guilford Press.

Milburn, T. F., Girolametto, L., Weitzman, E., \& Greenberg, J. (2014). Enhancing preschool educators' ability to facilitate conversations during shared book reading. Journal of Early Childhood Literacy, 14(1), 105-140. doi: 10.1177/1468798413478261

Nagy, W. E., Anderson, R. C., \& Herman, P. A. (1987). Learning word meanings from context during normal reading. American Educational Research Journal, 24(2), 237-270. doi: 10.3102/00028312024002237

Namasivayam, A. M., Hipfner-Boucher, K., Milburn, T., Witzmanm, E., Greenberg, J., Pelletier, J., \& Girolametto, L. (2015). Effects of coaching on educators' vocabulary-teaching strategies during shared reading. International Journal of Speech-Language Pathology, 17(4), 346-356. doi: 10.3109/17549507.2014.979871

Pedromônico, M. R. M., Bragatto, E. L., \& Strobilius, R. (1999). Teste de Triagem Denver II. São Paulo: Unifesp.

Pollard-Durpdola, S. D., Gonzalex, J. E., Simmons, D. C., Knok, O., Taylor, A. B., Davis. M. J., Kim, M., \& Simmons, L. (2011). The effects of an intensive shared book-reading intervention for preschool children at risk for vocabulary delay. Exceptional Children, 77(2), 161-183. doi: 10.1177/001440291107700202

Quinn, J. M., Wagner, R. K., Petscher, Y., \& Lopez, D. (2015). Developmental relations between vocabulary knowledge and reading comprehension: A latent change score modeling study. 
Child Development, 86(1), 159-175. doi: 10.1111/ cdev.12292

R Core Team (2018). R: a language and environment for statistical computing. R Foundation for Statistical Computing, Vienna, Austria. Retirado de http:/ /www.R-project.org/

Rogoski, B. de N., Flores, E. P., Gauche, G., Coêlho, R. F., \& de Souza, C. B. A. (2015). Compreensão após leitura dialógica: Efeitos de dicas, sondas e reforçamento diferencial baseado em funções narrativas. Perspectivas em Análise do Comportamento, 6(1), 48-59. doi: 10.18761/pac.2015.6.1.a04

Sénéchal, M. (1997). The differential effect of storybook reading on preschoolers' acquisition of expressive and receptive vocabulary. Journal of Child Language, 24, 123-138. Retirado de https:// psycnet.apa.org/record/1997-06323-006

Sidman, M. (1994). Equivalence relations and behavior: $A$ research story. Boston: Authors Cooperative.

Vallotton, C. D., Mastergeorge, A., Foster, T., Decker, K. B., \& Ayoub, C. (2017). Parenting supports for early vocabulary development: Specific effects of sensitivity and stimulation through infancy. Infancy, 22(1), 78-107. doi: 10.1111/infa.12147

Walsh, B. A., \& Blewitt, P. (2006). The effect of questioning style during storybook reading on novel vocabulary acquisition of preschoolers. Early Childhood Education Journal, 33(4), 273-278. doi: 10.1007/s10643-005-0052-0

Wasik, B. A., \& Hindman, A. H. (2014). Understanding the active ingredients in an effective preschool vocabulary intervention: An exploratory study of teacher and child talk during book reading. Early Education and Development, 25, 1035-1056. doi: 10.1080/10409289.2014.896064

Wilkinson, K. S., \& Houston-Price, C. (2013). Once upon a time, there was a pulchritudinous pricenss...: The role of word definition and multiple story contexts in children's learning of difficult vocabulary. Applied Psycholinguistics, 34, 591-613. doi: 10.1017/S0142716411000889

Recebido em: 08/02/2019

Reformulado em: 20/11/2019

Aprovado em: 29/11/2019 
Acknowledgments:

Financial support: National Council for Scientific and Technological Development (CNPq, process $\mathrm{n}^{\circ}$ 465686/2014-1 and 141780/2019-3) and FAPESP (process n ${ }^{\circ} 2014 / 50909-8$ ).

About the authors:

Ana Carolina Arruda Miranda is graduated in Psychology at Federal Fluminense University (UFF) and holds Master's degree on Science, with emphasis on Psychobiology at University of São Paulo. She is currently a doctoral student at Psychobiology Graduate Program at University of São Paulo and member of National Institute of Science and Technology on Behavior, Cognition and Teaching (INCT-ECCE).

ORCID: https://orcid.org/0000-0003-1090-054X

E-mail: anacarolina0301@usp.br

Claudia Daiane Batista Bettio is graduated in Psychology at State University of Maringá (UEM) and holds Master's degree on Science, with emphasis on Psychobiology at University of São Paulo. She is currently a doctoral student at Psychobiology Graduate Program at University of São Paulo and member of National Institute of Science and Technology on Behavior, Cognition and Teaching (INCT-ECCE).

ORCID: https://orcid.org/0000-0002-3294-0238

E-mail: claudia.bettio@usp.br

Andréia Schmidt is graduated in Psychology at Federal University of Paraná (UFPR), PhD in Psychology, (Experimental Psychology) at University of São Paulo. She is currently professor of Psychology at University of São Paulo, professor on Psychobiology Graduate Program and member of National Institute of Science and Technology on Behavior, Cognition and Teaching (INCT-ECCE).

ORCID: https://orcid.org/0000-0002-8836-6618

E-mail:aschmidt@ffclrp.usp.br

Contact:

University of São Paulo, Faculty of Philosophy, Science and Letters at Ribeirão Preto

Department of Psychology

Av. Bandeirantes, 3900, Monte Alegre

Ribeirão Preto, SP, Brazil

CEP: 14040-901

Psico-USF, Bragança Paulista, v. 25, n. 4, p. 671-683, out./ dez. 2020 